DOI 10.15826/qr.2015.3.121

УДК 81'373.211+81-119+81-21+81'286

Тамара Матвеева

Валентин Лукьянин

\begin{abstract}
АЛЕКСАНДР КОНСТАНТИНОВИЧ МАТВЕЕВ. ОНОМАТОЛОГ И ИССЛЕДОВАТЕЛЬ ДРЕВНИХ ЯЗЫКОВЫХ КОНТАКТОВ
\end{abstract}

Tamara Matveeva

Valentin Lukianin

\title{
ALEKSANDR KONSTANTINOVICH MATVEEV. AN ONOMATOLOGIST AND RESEARCHER OF ANCIENT LANGUAGE CONTACTS
}

The article considers the personality and research activity of Aleksandr Konstantinovich Matveev (1926-2010), an outstanding Russian linguist, corresponding member of the Russian Academy of Sciences and professor of Ural State University (presently, Ural Federal University). Specializing in the study of proper names (onomatology), Professor Matveev argued that the class of geographical names was crucial for the reconstruction of ethno-historical data on the former distribution of tribes and peoples in the vast territories of present-day Russia.

Among his achievements is the development of principles and methods of onomastic research based on field material collected by means of frontal survey. With the view of collecting linguistic material, A. K. Matveev established the Toponymic Expedition of Ural University that explored a number of northern regions of European Russia as well as the Northern and Middle Urals. During a 50-year period, the expedition collected millions on onomastic and lexical units. The unique card files stored at the department established by him at Ural Federal University are used as a basis for theses and other research as well as dictionaries, and they are used to correct cartographic data.

The central issue of the scholar's research was that of substrate in Russian toponymy. Together with his acolytes and colleagues, he searched for Finno-Ugric (Chud) and Merya language heritage in the Russian North, and Mansi loan words in the Northern Urals. The research material was analyzed with the help of a complex of methods (i. e. interlingual phonetic and other comparisons, the linguo-geographic method of cartographing and comparisons with data provided by related disciplines). Professor Matveev's findings and the find- 
ings of the Ural Toponymic Research School appear in onomastic and lexical dictionaries. The final conclusions of their toponymic research go far beyond linguistics and have a historico-ethnic character.

Professor Matveev is an eminent figure who evokes the memories of world-famous linguists-travellers of the past. He combines the audacity of a discoverer, the rigor of a scholar-including excellent organizing skills-the spirit of a zealous protector of his homeland's spiritual culture and the talent of a teacher. People were drawn to him by his vast erudition and versatile interests, and his humaneness combined with devotion to his research interests. A. K. Matveev's Research School and the Toponymic Expedition continue their intensive work until the present day.

Keywords: A. K. Matveev; etymology; onomastics; toponymy; substrate; language contacts; Russian North; Urals; Ural Toponymic Research School.

Описывается личность и научная деятельность выдающегося русского лингвиста, члена-корреспондента Российской академии наук, профессора Уральского государственного университета (ныне УрФУ) Александра Константиновича Матвеева (1926-2010). Его научные интересы были сосредоточены на изучении собственных имен (ономатологии), в области которых профессор Матвеев поставил на особую высоту класс географических названий по их значимости для восстановления этноисторических сведений о былом расселении племен и народов на обширных территориях современной России.

В его заслуги входит разработка принципов и методов ономастического исследования на основе полевого фронтально собранного материала. Для сбора языкового материала А. К. Матвеевым была организована Топонимическая экспедиция Уральского университета, обследовавшая целый ряд областей севера европейской части России, а также Северного и Среднего Урала и за пятьдесят с лишним лет накопившая миллионы фиксаций ономастических и лексических единиц. Уникальные картотеки экспедиции, хранящиеся на созданной им кафедре в Уральском федеральном университете, служат основой диссертационных и других научных исследований, словарей, корректировки картографических данных.

Центральной для ученого являлась проблема субстрата в русской топонимии. Вместе с учениками и коллегами он искал финно-угорское (чудское) и мерянское языковое наследие на Русском Севере, мансийские заимствования - на Северном Урале. Материал исследования изучался комплексно (применялись межъязыковые фонетические и прочие сопоставления, лингвогеографический метод картографирования, сопоставление с данными смежных наук). Результаты работы А. К. Матвеева и основанной им Уральской топонимической научной школы отражены в ономастических и лексических словарях. Конечные же научные выводы топонимических изысканий выходят за пределы лингвистики и носят историко-этнический характер. 
Профессор Матвеев - яркая личность, заставляющая вспомнить о всемирно известных лингвистах-путешественниках прошлого. В нем соединены дерзость первооткрывателя, скрупулезность кабинетного ученого, организационные способности, совесть ревнителя отечественной духовной культуры, педагогический талант. Широчайшая эрудиция, разносторонние интересы, человечность при поглощенности своим основным делом привлекали к нему людей. Научная школа А. К. Матвеева и Топонимическая экспедиция продолжают активную деятельность.

Ключевые слова: А. К. Матвеев, этимология, ономастика, топонимия, субстрат, языковые контакты, Русский Север, Урал, Уральская топонимическая школа.

Вверх по реке забвения... Это название одной из научно-художественных книг А. К. Матвеева и самая суть научной профессии ее автора. Забвение прошлого естественно, неотвратимо, необратимо, но именно наперекор этому идет наука этимология, цель которой выяснение истоков слова. А за словом стоит история народа, точнее, различных народов, поскольку их судьбы пересекаются, а контакты отражаются в языке и сохраняются языком.

\section{Университетский стиль}

Александр Константинович Матвеев - выдающийся русский лингвист-этимолог, финно-угровед, диалектолог, исследователь древних языковых контактов русских с исконным населением различных территорий современной России. Всю свою профессиональную жизнь он провел в Уральском государственном университете (УрГУ)1, великолепно владея университетским стилем преподавания. Этот стиль требует приобщения студентов к занятиям наукой, пробуждения интереса к интеллектуальным открытиям, вовлечения в научное сообщество. Именно это качество работы Матвеева позволило создать Уральскую топонимическую школу.

Школа предполагает наличие единой концепции, а также нескольких поколений учителей и учеников и проявляется в применении выработанной суммы методов к определенному крупному объекту. Но у основ школы - всегда личность, персональная идеология и научная отвага которой задают первоначальный импульс и обозначают направление поиска, а длительное личное волевое усилие удерживает заданную стратегию и обеспечивает результативность движения.

Уральская топонимическая школа этимологов, признанная в России и Европе, основана в городе Свердловске (ныне Екатеринбург) в

${ }^{1}$ В 2010 г. на основе Уральского государственного университета и Уральского государственного технического университета - УПИ был создан Уральский федеральный университет. 
начале шестидесятых годов XX в. Все начиналось со студенческого кружка сравнительно-исторического языкознания, организованного доцентом А. К. Матвеевым. Ономастика и этнонимия - вот круг первоначальных интересов этого научного общества, очень молодого и ревностно относящегося к научной работе.

Открыв первый выпуск авторитетного сейчас периодического издания «Вопросы топономастики» [ВТ] (он вышел с подзаголовком «Доклады кружка сравнительно-исторического языкознания»), легко убедиться в единстве принципов научной работы авторов сборника. Все статьи строятся на собственном материале, собранном на основе географических карт и других письменных источников, а также непосредственно на местах его бытования. Широко применяется метод лингвистического картографирования, цель которого - установление ареалов распространения изучаемого явления. Обязательна и основательна сверка собственных наблюдений с данными смежных наук. А главное, лингвистические наблюдения в конечном итоге ставятся на службу истории, лингвистические данные понимаются как аргументы историко-этнических выводов.

Удивительно сейчас, более полувека спустя, осознать, что в этой маленькой (49 страниц) брошюре, из восьми авторов которой семеро - это студенты, уже намечена серьезная программа научных действий. Здесь очерчен круг проблем (этимология собственных имен, особенно субстратных географических названий, а в конечном счете - проблема заселения территорий современной России в доисторические времена), обозначены основные области лингвистического обследования (Русский европейский Север и Урал), определены опорные принципы и методы исследования (предпочтение массированного материала, фронтально собранного в полевых условиях, его обязательное картографирование, комплексный подход, предполагающий учет параллельных этнографических и археологических данных, системность лингвистических наблюдений и межъязыковых сопоставлений).

Впрочем, удивительно ли? Если сосредоточиться на личности руководителя данной научной группы, удивление пропадает. В начале шестидесятых А. К. Матвеев уже кандидат филологических наук, защитивший диссертацию на тему «Финно-угорские заимствования в русских говорах Северного Урала», в которой исследователь четко формулирует общую задачу этимологических разысканий в области диалектной лексики: «Изучение семантики диалектных заимствований и путей их проникновения из одного языка в другой нередко помогает раскрыть разнообразные исторические связи между народами, а в некоторых случаях даже установить их хронологию» [Матвеев, 1959, с. 3]. Сформулирован основной принцип сбора материала требование «многократных поездок во многие районы Северного Урала, изучения особенностей местной природы, экономики и быта, а также направленного опроса местных жителей» [Там же, с. 4]. 
В процессе подготовки диссертации за четыре года состоялось восемь выездов на полевой сбор материала, которые включали многочисленные беседы с мансийскими оленеводами, охотниками-коми, русскими крестьянами-старообрядцами. Так обеспечивалась достоверность научных данных, так наблюдения языковеда ставились на твердую почву комплексного подхода в области этимологии.

В диссертации А. К. Матвеевым были сделаны и некоторые наблюдения, касающиеся географических названий. Он отмечает наличие особой семантической группы, образованной географическими терминами, которые воспринимаются то как нарицательные, то как собственные. Это свидетельствует о тесной связи топонимики и географической терминологии и открывает дорогу к этимологии топонимов, установлению дорусских пластов топонимики и выявлению древнеуральских топонимических элементов [Там же, с. 114-115]. Оценим смелость этой позиции в контексте истории науки. Собственные имена - так считалось - не имеют лексического значения в общепринятом понимании, следовательно, с точки зрения этимологии это непознаваемый объект. Сделать его познаваемым и поставить на историко-культурологическую службу - одним из первых в российской науке такую сверхзадачу ставит перед собой этимолог А. К. Матвеев.

Ее решение требовало научного новаторства, новых методов, пересмотра целого ряда сложившихся подходов. Сила и смелость ученого проявились в том, что он брал научный процесс изучения собственных имен в полном объеме: от правильного сбора материала до установления этноисторических выводов. Матвеев - лингвист, который предпосылал лингвистике географию и шел дальше лингвистики в историю языковых контактов. При этом он нисколько не пренебрегал собственно лингвистикой: тщательным фонетическим и семантическим анализом, изучением русской адаптации иноязычного слова, учетом языкового фона и диалектного расслоения контактирующих языков. И конечно, важна системность подхода. Сбор материала должен быть сплошным, с фронтальным обследованием обширных территорий, интерпретация ономастических множеств - ареальной, с нанесением на карту однотипных групп топонимов, сопоставительная база - максимальной, с учетом данных археологии, этнографии, географии, ботаники, зоологии, экономики и других наук.

\section{Генеалогия личности}

Профессиональный успех неизбежно пробуждает сомасштабный интерес к личности.

Следуя английской шутке, чтобы стать настоящим джентльменом, недостаточно окончить Оксфорд. Нужно, чтобы Оксфорд окончили и твой отец, и твой дед. Это имеет прямое отношение к нашему герою, поскольку подсказывает, где кроется объяснение таланту первоот- 
крывателя. Коренной свердловчанин, потомок уральских мастеровых оканчивает Хабаровский пединститут, а по возвращении в Свердловск покоряет студентов и коллег широтой эрудиции, безупречно поставленной речью, тем простым и внятным стилем общения с окружающими, в котором угадывался неподдельный аристократизм духа. Конечно, истоки личности Александра Константиновича нужно искать в его неординарной семье.

Отец его, Константин Константинович Матвеев, - известнейшая фигура в истории высшего образования на Урале. Уроженец уездного уральского городка Камышлова, он в 1907 г. окончил естественное отделение Петербургского университета, по праву считал себя учеником и соратником В. И. Вернадского и А. Е. Ферсмана. Совсем молодым завоевал известность как геолог и минералог, в его честь даже назван минерал - матвееви́m. С 1913 по 1918 г. Константин Константинович был ученым секретарем Радиевой комиссии Академии наук, состоял в Уральском обществе любителей естествознания. Когда в 1914-1917 гг. был учрежден Уральский горный институт, К. К. Матвеев стал одним из его первых профессоров, некоторое время был ректором. Он организовал кафедру минералогии и кристаллографии, а также минералогический музей, который хорошо известен на Урале.

О матери Александр Константинович всегда отзывался не просто с сыновьей теплотой, но и с подлинной нежностью и огромным уважением: она на самом деле была одаренной и прекрасно образованной. Знала несколько европейских языков, играла на фортепиано и любила оперу, с детства вела дневник, который, по словам сына, свидетельствовал «о глубоком нетривиальном уме, тяге к прекрасному, отличном литературном вкусе», оставила мемуары ${ }^{2}$. Ксения Михайловна принадлежит древнему дворянскому роду Лёвшиных, корни которого прослеживаются с XIV в. C 1920 г. она преподавала английский язык в Уральском горном институте; в 1930 г. там была организована кафедра иностранных языков, и К. М. Лёвшина стала первым ее заведующим. Уже в преклонном возрасте, находясь в военном Хабаровске, служила референтом ТАСС, занималась переводами с итальянского и французского. В семье было восемь детей. Саша - седьмой. Трое из них умерли в детстве, старший сын Андрей, геолог Дальневосточного геологического управления, пройдя через самое пекло Великой Отечественной войны, погиб в феврале 1945-го. Прямая дорога Александра, казалось, тоже в геологи, по стопам отца и старшего брата. Он и поступил на геологический факультет в военном 1943 г. Осенний сезон провел в геологической партии, откуда был призван в армию. Службу проходил в Челябинском военном авиационном училище штурманов и стрелков-радистов авиации дальнего действия, получил воинское звание старшины. В 1945 г. был демоби-

\footnotetext{
2 Часть их, на русском языке, подготовлена к печати сыном и внучками и опубликована, см.: [Лёвшина].
} 
лизован и уехал в Хабаровск, к матери, там окончил филологический факультет пединститута.

Очевидно, в обстановке тех трудных лет не могло быть и речи о каких-то особенных условиях для его развития, кроме семейного воспитания и традиции. Отец брал сына в геологические экспедиции, обсуждал с ним коллекционирование марок. Под влиянием матери Александр много читал (к двенадцати годам был прочитан весь Шекспир), приобщался к театру. И хотя всего год удалось позаниматься музыкой, но тяга к искусству осталась на всю жизнь (он снова начал брать уроки музыки, когда ему было уже около пятидесяти, и всю дальнейшую жизнь считал за счастье провести час-другой за музицированием). В семье с высоким культурным потенциалом и традицией трудолюбия формируется тот стартовый духовный капитал, с которым появился в Уральском университете выпускник провинциального педагогического института. Преподавать он начал еще в Хабаровске, будучи студентом-старшекурсником, а затем выпускником (вел античную литературу и латинский язык). Обретение широты эрудиции и культуры мышления, которые отличали А. Матвеева уже в самом начале его профессионального становления, предполагали целенаправленную работу над собой, и вот эта неординарная работоспособность резко выделяла его в университетской среде.

Он был жаден до интеллектуального труда. Свидетельство тому служебная записка П. А. Шуйского, его старшего (примерно на полвека) коллеги и заведующего кафедрой классической филологии Уральского университета, на которую в 1952 г. был принят молодой преподаватель. В июне 1954 г. завкафедрой, в частности, отмечает: «Преподаватель А. К. Матвеев, три года работы у нас, разносторонне способный, успевший приобрести наибольшую популярность среди студентов, вследствие чего считающий себя неизмеримо выше всех других, легко берущийся за проведение многих предметов (средневековая латынь, античная литература, сравнительная грамматика индоевропейских языков, греческий язык, восточная литература)» ${ }^{3}$. У начинающего преподавателя хватало профессиональной дерзости браться за преподавание сложных предметов экзотической по тем временам кафедры, ветераны которой свободно говорили на латыни и греческом. При этом античную литературу читал так профессионально, что студенты предпочитали ее современной. Латынью привлекал, декламируя наизусть гекзаметры и демонстрируя рациональность грамматической системы.

Но собственное научное направление А. К. Матвеевым в середине пятидесятых годов еще не было найдено. Читая служебную записку П. А. Шуйского дальше, узнаём, что это молодой преподаватель, «легко переходящий от одной специальности к другой, отказавшийся уже от четырех кандидатских тем и теперь “твердо” решивший специали-

${ }^{3}$ Архив музея УрГУ, ф. 63 (Личный фонд П. А. Шуйского), д. 2. 
зироваться по одному из предметов кафедры русского языка и общей лингвистики». Тему для себя он хочет определить самостоятельно, что удается не сразу как раз из-за необычайной широты его филологических интересов. Но установка во всем искать собственный путь определяет его научную биографию и жизненные этапы.

В дальних походах и диалектологических вылазках Александр Константинович почувствовал вкус к местным словечкам, от которых веяло историей никак не меньше, чем от языков классической древности, при том что говорами Урала, а тем более языковыми следами его коренных обитателей тогда никто еще всерьез не занимался. Неведомые страницы истории языка ждали своего исследователя. Заимствования в русских диалектах определились как научная тема, на базе которой позднее сформировался интерес к проблеме субстрата в топонимии. С самой первой поездки на Северный Урал, когда А. К. Матвеев в одиночку отправился собирать материал в деревнях на Пелыме и Вагиле, началось осознание собственной позиции: народное слово - памятник русской истории и культуры. Хорошо осознавалась уязвимость объекта изучения. Урбанизация, которая шла полным ходом, влекла за собой «растворение» диалектов, изменение образа жизни коренных народов и современной картины языковых контактов. Целые пласты лексики, целые разряды имен собственных уходят вместе с изменением деревенского уклада жизни, с натиском цивилизации на жизнь кочевых народов. А. К. Матвеев принял на себя личную ответственность за сохранение русской истории, запечатленной в слове, и делал для этого все, что мог. Сбор и сохранение языкового материала стали для него не средством карьерного роста, а делом чести и совести.

\section{Топонимическая экспедиция}

А. К. Матвеев понимал, что его замысел требует создания экспедиции - постоянно действующей структуры, нацеленной на планомерное массовое лингвистическое обследование значительных территорий. И вот тут - хвала исследовательским устремлениям университета. Студенческий интерес к науке - это не пустяк, именно студенты-филологи, с их энтузиазмом и тягой к дальним странствиям, могут составить отряды собирателей слова, приобщаясь тем самым к истории языка. Основной объект изучения был уже ясен: древние географические названия России. Проблема их происхождения лежит на грани лингвистики с историей и географией. «Наиболее существенны при этом сведения, которые можно получить при изучении субстратной топонимии, т. е. реликтов вымерших языков, сохранившихся в том или ином функционирующем языке, например, в русском» [Матвеев, 1986, с. 3]. Специфика материала требовала собирать его непосредственно в местах бытования. 
Организационная опора научных экспедиций в советских университетах была обусловлена программой обучения на филологическом факультете, предусматривавшей фольклорную и диалектологическую практики, с выездом студентов в сельскую местность и работой по определенной программе сбора материала. Кроме того, УрГУ располагал опытом археологических экспедиций. Лингвистическая экспедиция была делом новым, но в научном отношении понятным и профессионально значимым. Данное предприятие требовало отдельного немалого бюджетного финансирования, поскольку предполагалось обследование территорий Русского Севера. Но и на это Уральский университет пошел - очевидно, инициатор экспедиции располагал убедительными доводами. Главным из них были уже осуществленные пробные групповые выезды. В 1960 г., например, был путем сплава обследован бассейн реки Чусовой, собран ценный топонимический материал, заложивший первый камень будущего топонимического словаря [Иванова].

Студентами и сотрудниками кафедры идея экспедиции воспринималась «на ура», и желающих ехать было больше, чем нужно. Зимой 1961 г. отряд из пятнадцати человек под началом А. К. Матвеева отправляется в Архангельскую область (Верхнетоемский, Котласский, Обозерский, Пинежский, Холмогорский районы). От этой первой официальной поездки ведет счет Топонимическая экспедиция Уральского университета. Материал собирался на Русском Севере - в Архангельской, Кировской и Вологодской областях [Вброд через реку времени, с. 220-236]. Позже в работу были включены Костромская, Ярославская области и Саяны. Все большее значение приобретал уральский отряд экспедиции. С территорий Среднего Урала он постепенно перемещался на Северный и даже Приполярный Урал, в места мансийских кочевий. Транспортным средством становился вертолет, моторная лодка, а бывало, и оленьи нарты, предстояли и многокилометровые пешие переходы, но это лишь подогревало интерес студентов.

Ежегодно не менее двадцати человек из Уральского университета отправлялись на полевые работы. В первые годы в Архангельской области группы были маршрутные и стационарные. Маршрутные группы, проходя достаточно быстро заранее намеченный путь (например, по бассейну р. Вага в Архангельской области), выполняли беглый сбор материала и выявляли места, перспективные в плане поиска субстрата - дорусских географических названий. Стационарные группы останавливались в населенном пункте и работали на одном месте до полного обследования целого куста деревень. Среди сельского населения искали людей, обязательно коренных жителей, хорошо знающих окрестности: лесников, охотников, сплавщиков. Записывали не только названия рек, озер и населенных пунктов, но и уникальную микротопонимию: названия лесных урочищ, дорог, покосов, пожен, деревенских околотков. 
Перспективным в научном плане оказался метод сплошного фронтального сбора в стационарных условиях. На почтовых машинах и попутках, на рейсовых речных судах добирались до назначенного места, а от базы до соседних деревень - чаще всего пешком (зимой на лыжах). Начальник экспедиции перемещался из одной группы в другую, лично принимая участие в работе с информантами и контролируя процесс сбора слов.

А. К. Матвеевым была разработана научная система картографирования. Собранный группой материал проверялся на качество и количество. Каждое географическое название должно быть привязано на местности. Слово привязка постоянно витало в экспедиционных разговорах. Мало записать название ручья, например. Нужно еще последовательно указать, куда впадает этот ручей, справа или слева по течению, какие другие притоки имеются выше и ниже данного и на каком примерно расстоянии от него. Таким образом, название фиксировалось как единица лингвогеографической системы данной территории. Информантов должно быть несколько, а если их данные расходятся, нужно вести расследование дальше. Нужно сверять полученные сведения с теми, что имеются на картах леспромхозов, лесничеств, сельсоветов. Полагалось также учитывать сведения о размере, форме и других особенностях географического объекта, фиксировать ударение и различные варианты названий, записывать их употребление в мотивирующем и прочих контекстах. Конечно, отмечать образную народную интерпретацию топонимических метафор. А в конце не забыть указать место записи, имя информанта и свое собственное. Записывали также диалектную лексику, так что параллельно в УрГУ составилась картотека лексики говоров Русского Севера. Не проходили мимо других видов собственных имен: собирали и антропонимы, и клички животных, и местные названия растений.

Постепенно определялась и уточнялась методика целенаправленного опроса местных жителей. Если вначале в разговорах с информантом шли от здравого смысла и интуиции, то в дальнейшем были составлены инструкции, опросные листы, выявлена понятийная сетка, актуальная для сбора топонимического материала. В 1986 г. А. К. Матвеев обобщает результаты этой работы, обеспечивающей качество топонимического материала научных исследований, в учебном пособии «Методы топонимических исследований» [Матвеев, 1986].

На Урале же сформировалось особое направление экспедиционной работы. Основной задачей здесь становится сбор и уточнение исчезающей мансийской топонимии. Мансийский язык в 60-70-е гг. $\mathrm{XX}$ в. еще жив, но положение его уже очень шатко в связи с теми изменениями уклада жизни манси, которые произошли в советское время. Кочевничество ограничивалось, детей забирали из семей для обучения в школах-интернатах, разрывая тем самым потомственную передачу профессии оленевода и охотника. В местах кочевий активно работала геологоразведка. А. К. Матвеев хорошо понимал, что нужно 
спешить. «Утрата богатейшего пласта мансийской топонимии, относящейся к горной части Северного Урала, была бы непростительна», пишет ученый в предисловии к последней своей книге [Матвеев, 2011]. Он был прав. Перемены шли быстро, в настоящее время манси уже не пасут оленей, их летние каслания (кочевки) прекратились полностью. Но топонимическая экспедиция свое дело сделала.

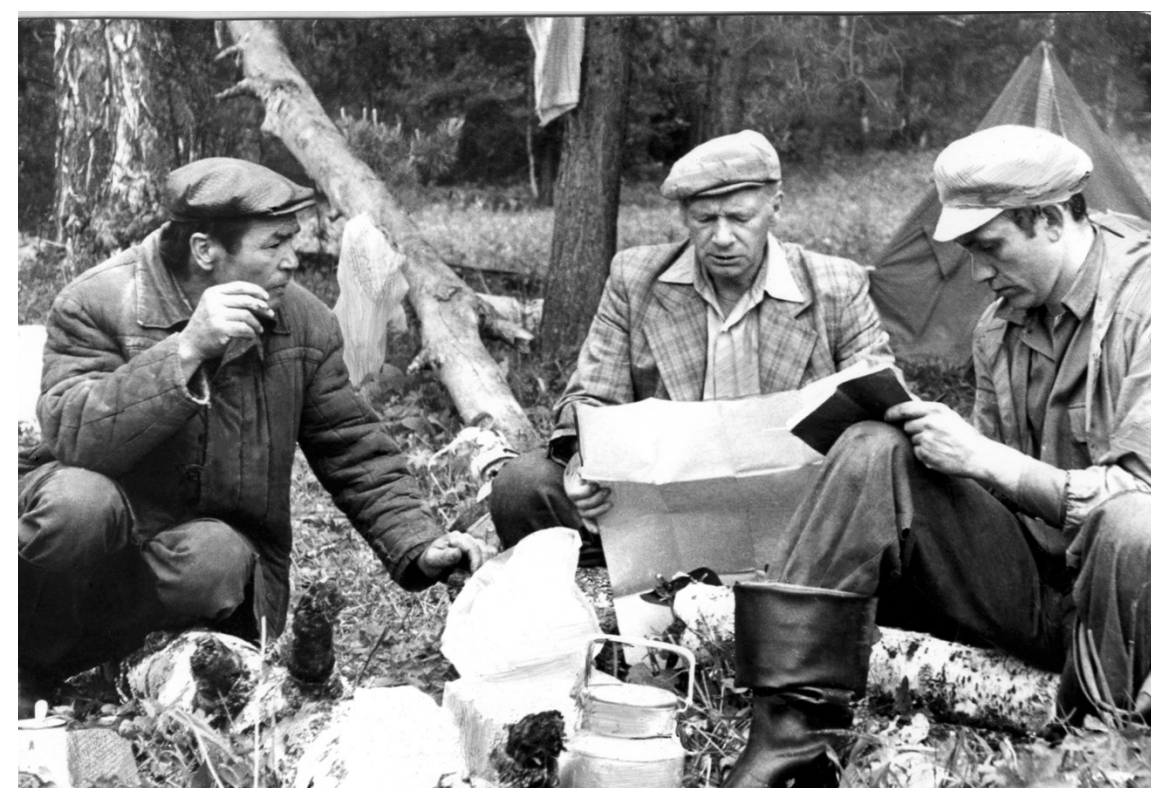

Работа с информантом. Мансийская экспедиция, Северный Урал

Шесть полноценных летних экспедиций на места мансийских кочевий и шесть зимних, разведочных и вспомогательных. Каждая из летних экспедиций длиной в месяц-полтора сложна и технически (передвижения только вертолетом), и прогностически (контакты с кочующими манси непредсказуемы). Трудна в бытовом отношении (жизнь в палатках и мансийских чумах, тяжелые погодные условия). В теоретическую подготовку участников входит изучение мансийского языка, без чего невозможно ни общение с коренными жителями, ни полноценный сбор языкового материала. Полгода перед первым выездом на Северный Урал А. К. Матвеев занимается мансийским языком с группой добровольцев. В работе опирались на данные выдающихся исследователей-одиночек, собиравших и изучавших мансийский язык на Северном Урале в XIX и первой трети XX в., - венгров Антала Регули и Берната Мункачи, финна Арттури Каннисто.

Собирали материал, отталкиваясь от отечественных словарей мансийского языка В. Н. Чернецова, А. А. Баландина и М. П. Вахрушевой, Е. И. Ромбандеевой. Результатом всей этой работы стала кар- 
тотека мансийской лексики и топонимики и существенное уточнение картографических данных по Северному Уралу (сколько ошибок допустили картографы, не будучи лингвистами и записывая местные названия со слуха!). Эти материалы послужили основой целого ряда статей, диссертаций [Глинских; Смирнов, 1997] и, много позже, обобщающего труда «Материалы по мансийской топонимии горной части Северного Урала» [Матвеев, 2011]. Эта книга была сдана в печать А. К. Матвеевым лично, а вышла в свет уже после его смерти. В нее вошел список мансийских географических терминов, обширный словарь мансийской топонимии и фундаментальная статья «Мансийская топонимия как лингвистический и историко-этнографический феномен». В заключении статьи А. К. Матвеев отмечает правдоподобие гипотезы о южном (лесостепном) происхождении манси и проводит аналогию семантики мансийских топонимов с содержательной стороной названий других народов Северной Азии, воспринявших христианство при сохранении в культуре языческих верований.

Если работа, подобная проведенной, будет осуществлена в других местах проживания этого народа, пишет А. К. Матвеев, то «языковая картина мира манси в ее топонимической ипостаси предстанет перед нами во всей полноте и красоте» [Матвеев, 2011, с. 255]. Надежды романтика от лингвистики. Других таких экспедиций не было. Лишь Т. Д. Слинкина с небольшой группой сотрудников Обско-угорского института прикладных исследований (г. Ханты-Мансийск) в 20032010 гг. собирала мансийские оронимы Урала в бассейнах Щугора, Печоры и Вишеры [Слинкина], и она застала последних стариков манси, оленеводов, которые когда-то кочевали по Уралу.

Четыре экспедиции в Саяны 1963-1966 гг. остались памятником исследовательской неуемности и отчасти научного авантюризма А. К. Матвеева. Начальнику экспедиции было мало Русского Севера и Урала, потянуло поискать уникальный субстрат в тофаларских деревнях на склонах Саянского хребта, проследить судьбу почти исчезнувшего малого народа Сибири. Ориентиры были получены на основе трудов Александра Кастрена, побывавшего на Саянах в 1847 г., и Кая Доннера, работавшего там в 1914 г. Оба финских языковеда выделяли деревню Абалаково на северных отрогах Саян как место, в районе которого жил народ калмажей - камасинцы. Уже в начале XX в. этот народ был на грани исчезновения, К. Доннер зафиксировал лишь 40-45 человек, знающих родной камасинский язык, на основе бесед с ними (он два месяца провел в Абалаково) составил небольшой (около 900 единиц) словарь. Как было Матвееву не удостовериться, что произошло с камасинским языком и какова местная топонимия, обязательно несущая в себе его следы?

Саянский отряд Топонимической экспедиции ставил цель собрать камасинские географические названия, а также проверить на месте сам факт исчезновения камасинского языка [Матвеев, 1964]. Язык maежных mamap (так называли камасинцев местные жители) считал- 


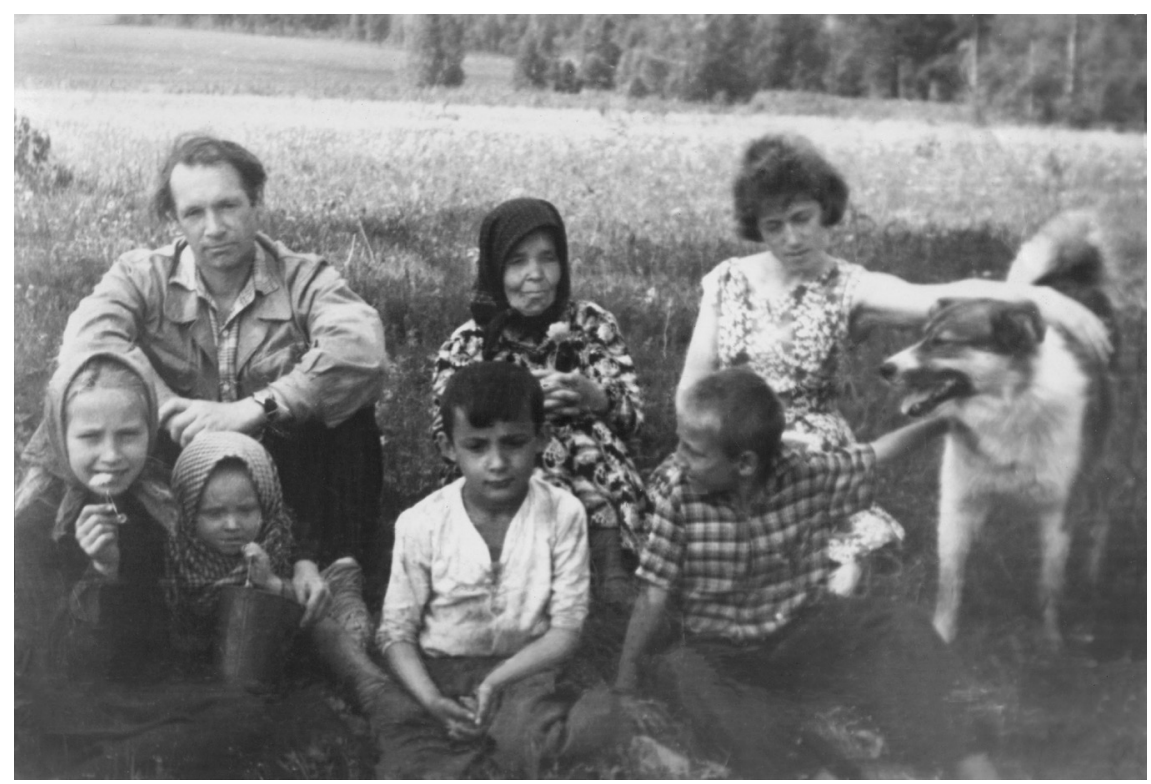

Саянская экспедиция. Деревня Абалаково, 1960-е гг.

ся мертвым, и этот факт, к сожалению, подтвердился. В Абалаково не только никто не говорил по-камасински, но и сообщить какие-либо сведения о коренных жителях не могли ни русские, ни украинцы, населявшие теперь эти места. Топонимический материал был невелик, генеалогические схемы к нужному результату не приводили. Научная неудача, к которой в общем-то все были заранее морально подготовлены.

И вдруг - нечаянный случай. Деревенская старушка, продав заезжим людям молока, сказала что-то на незнакомом языке. Удалось записать от нее несколько камасинских слов. А далее каждый день по нескольку часов участники экспедиции разговаривали с Клавдией Захаровной Анджигатовой, которая уже много лет до того не говорила по-таежному (не с кем стало говорить), но кое-что помнила. Приезжали к ней несколько лет, уже с записывающей, очень несовершенной тогда, техникой, и в долгих разговорах всплывал, всплывал из личной памяти и одновременно из исторического небытия погибший язык. Такое вот научное чудо. Случай, по общему правилу, произошедший с тем, кто был готов его поймать. Этой научной сенсацией сразу заинтересовались эстонские лингвисты. А. К. Матвеев ввел в состав саянского отряда молодого ученого из Тарту Аго Кюннапа, и позднее передал ему все камасинские материалы. Редкий акт научного бескорыстия. Эстонские финно-угроведы имели богатую традицию изучения самодийских языков, к которым относится камасинский, 一 им и карты в руки. Матвеев же вернулся к своим основным территориям, Русскому Северу и Уралу. Он их, впрочем, и не бросал. Просто в эти 
годы экспедиция работала по двум, а то и сразу по трем направлениям. Вот, к примеру, в 1966-м: Свердловская область, Гаринский район; Архангельская область, Верхнетоемский район; Кировская область, бассейн р. Молома; Саяны, д. Абалаково.

Многолетняя полевая работа сплотила людей. Об этом спустя несколько десятилетий пишет О. В. Востриков: «Экспедиция когда-то стала пусковым механизмом кристаллизации собственно “матвеевского” коллектива единомышленников, она стала идеальным средством синтеза науки и практики, объединения преподавателей и студентов, соединения высокого служения науке и человеческих, личных, по-домашнему теплых отношений» [Востриков, 2015a, с. 173].

Сотни участников внесли свою лепту в работу Топонимической экспедиции Уральского университета. В Свердловск - Екатеринбург потекли ежегодно добываемые на месте картотеки. В университете они сливались в общую картотеку, число единиц которой определяется уже семизначной цифрой, постоянно меняющейся в сторону увеличения. В 2016 г. будет 55 лет с того первого архангельского выезда, и столько же лет сбора бесценного, уникального словесного материала. И топонимического, по Русскому Северу и Уралу, и диалектного лексического.

Систематизация картотеки, управление ею требовало все большего времени и специальных усилий. А. К. Матвеев добивается создания научно-учебной топонимической лаборатории при кафедре. Это очень серьезная заявка: дополнить структуру университета новым отделением, с полноправными сотрудниками и долгосрочной программой работы. Непросто было аргументировать ректору и Министерству образования целесообразность такого шага. Но главные аргументы были налицо: сама картотека - овеществленный результат двадцати лет работы экспедиции, а также сама уже фактически работающая лаборатория. В 1981 г. топонимическая лаборатория сменила статус и стала штатным подразделением Уральского государственного университета. А. К. Матвеев руководил лабораторией в течение 23 лет.

В настоящее время постоянно пополняемая картотека силами сотрудников топонимической лаборатории переводится на электронные носители, создается электронная база данных по топонимии Русского Севера [Николаева; Макарова; Мищенко]. Тем самым к материалам открывается доступ для всех ученых-ономатологов России и других стран.

\section{Научные результаты}

Собранный экспедицией материал никогда не считался конечной целью работы. Он был нужен для постановки научных задач, малых и больших, а в конечном счете для достижения амбициозной цели - на основании языковых данных получить сведения о древнем расселе- 
нии и взаимных контактах коренных народов на изучаемых территориях России. Университетская система имела свои преимущества в привлечении новых сил для исследования, что оптимально использовалось А. К. Матвеевым.

Установка на научный результат была задана с самого начала работы экспедиции и кафедры истории русского языка и общего языкознания. Каждый новый участник экспедиции - и студент, специализирующийся на кафедре, и сотрудник лаборатории, а уж преподаватель тем более - мягко и настойчиво побуждался Матвеевым к научному исследованию и мог получить конкретную тему для наблюдений и выводов. Самостоятельность поощрялась, консультации подразумевались. Постоянное общение научного содержания, помимо экспедиционных сборов-разговоров, происходило в рамках топонимической лаборатории, кафедральных семинаров, конференций. Кафедра общего языкознания по праву гордится тем, что ею были организованы первая в стране Всесоюзная студенческая научная конференция по теме исследований (1971), а затем последующие подобные. Многие маститые ученые-ономатологи (Н. Д. Голев, И. И. Муллонен, Л. М. Дмитриева, В. И. Супрун, Н. В. Лабунец и др.) приобщались к науке на этих встречах, их первые публикации появились в Свердловске.

Строгий научный надзор за качеством всего публикуемого учениками был у Матвеева неуклонным и постоянным. Студенты становились аспирантами, но контроль не ослабевал. Н. В. Кабинина в своих воспоминаниях пишет: «В аспирантуре меня поражало: как бы ни был занят А. К. Матвеев, он внимательнейшим образом просматривал и редактировал черновики всех наших аспирантских публикаций. Казалось бы, в ситуации 1990-х, когда стало возможным публиковать практически все, что угодно, эта опека была излишней, только отнимала время. Но Александр Константинович так не считал. Исправленные его рукой свои первые творения мы переделывали с большим трудом, по нескольку раз, иногда доходя до отчаяния. Но в какой-то момент каждый из нас осознавал, что его забота о наших публикациях рождалась не из какого-то там непонятного педантизма, а из верности истинной науке, из глубочайшего неприятия всяческой легковесной наукообразной продукции. С этим приходило и понимание того, что он считал нас достойными идти не просто в науку, а в настоящую науку» [Кабинина, 2015, с. 191].

И конечно же, он очень много и целенаправленно работал сам. Главной научной темой А. К. Матвеева стал субстрат - древние заимствования в составе русского языка Он пришел к этой теме от своей кандидатской диссертации по лексическим заимствованиям, сузив направленность научного поиска рамками древних заимствований и избрав основным объектом своих наблюдений географические названия. Научные изыскания Матвеева сделали его известным лингвистическому сообществу не только России, но и за 
рубежом. Его публикации были известны в Москве, Киеве, Таллине, Риге, Будапеште, Хельсинки. Его статьи брали известные профильные журналы «Советское финно-угроведение», венгерские «Acta linguistica» и «Nyelvtudomanyi Közlemenyek»². В 1968 г. академик В. В. Виноградов от лица редколлегии журнала «Вопросы языкознания» обращается «к известному специалисту в области теоретической разработки вопросов топономастики» с предложением: «написать для нашего журнала статью на любую интересующую Вас тему» ${ }^{5}$. Интересно, что ряд работ публикуется за пределами филологических изданий, в сборниках и журналах «Вопросы истории Урала», «Отчеты Камской археологической экспедиции», «Вопросы географии», «Геодезия и картография».

Проблематика публикаций А. К. Матвеева разнообразна (см. Список научных трудов профессора Матвеева в издании [Язык и прошлое народа, с. 476-501]). Множество конкретных топонимических этимологий, структурно-фонетический анализ субстратных топонимов и фонетического усвоения последних, топонимическая типология, бытование географических терминов в составе топонимии, топонимические ареалы и изоглоссы, методы топонимических исследований, принцип семантической мотивированности, история топонимических исследований, дофинноугорский субстрат, образное народное видение в связи с этимологической интерпретацией, древнейшие места расселения финнов, угорских народов, самодийцев.

Искать финно-угорский след на Русском Севере - такова была задача, поставленная в докторской диссертации [Матвеев, 1970], которую он защитил в Институте русского языка АН СССР. В ней были представлены доказательства языковых контактов на изучаемой территории и определены ареалы распространения древних языков, получила законченное оформление методология этимологического анализа субстратной топонимии и был выведен «закон семантической мотивированности топонимов, раз и навсегда отметающий рассуждения о произвольности и непознаваемости причин возникновения географических собственных имен» [Рут, Березович, с. 73]. Позднее ученый занимается и топонимическим субстратом Уральского Севера [Матвеев, 1987b].

Вновь и вновь обращаясь к этимологии, картографированию и стратификации субстратной топонимии Русского Севера, профессор Матвеев разрабатывает эту проблему методом «квадратно-гнездовых раскопок» [Востриков, 2015b, с. 21]. Он делает целый ряд выводов о наличии и соотношении на данной территории прибалтийско-финского, саамского, «севернофинского» пластов и об отсутствии угорских и самодийских проявлений, фиксирует мерянский топонимический ареал (подробнее см.: [Аникин; Смирнов, 2015]).

\footnotetext{
${ }^{4}$ См.: [Матвеев Александр Константинович. Библиографический указатель].

${ }_{5}^{5}$ Факсимиле цитируемого письма из архива А. К. Матвеева воспроизведено на заднем форзаце книги: [Не просто прожитая жизнь].
} 
За свои научные и организационно-научные достижения професcop А. К. Матвеев в 1988 г. получил почетное звание «Заслуженный деятель науки РСФСР», а в 1991 г. был избран членом-корреспондентом Российской академии наук.

Когда наступает время обобщений, член-корреспондент Российской академии наук публикует серию монографий с названием «Субстратная топонимия Русского Севера» (СТРС). Первые три части этого фундаментального труда [Матвеев, 2001; 2004; 2007] посвящены прибалтийско-финской и саамской топонимии, а также реликтам исчезнувших языков, которые условно названы А. К. Матвеевым севернобинскими.

Четвертую часть своего выдающегося труда по субстратной топонимии Русского Севера А. К. Матвеев закончить не успел. О. В. Смирнов пишет: «Это исследование должно было перекинуть своеобразный мостик с территории Русского Севера на земли Центральной России, раскрыть древнюю языковую связь финно-угорского населения этих территорий. Связующим звеном, по мнению А. К. Матвеева, служит топонимия мерянского типа, т. е. наследие мерянского языка и близких к нему диалектов, следы которых обнаруживаются в том числе и на Русском Севере ${ }^{6} .$. Безусловной ценностью незаконченной книги является предпринятое А. К. Матвеевым этимологическое исследование субстратной топонимии территории Центральной России: исторических мерянских земель (ИМЗ). Представленные в этом исследовании этимологии дают ценнейший материал для реконструкции мерянского языка и родственных диалектов» [Смирнов, 2015 , с. 7]. Цитируемый автор, ученик А. К. Матвеева О. В. Смирнов, подготовил к печати CTPC-IV, и завершающая часть четырехтомника вышла в свет [Матвеев, 2015].

Здесь же скажем, что несколько крупных работ были опубликованы уже после ухода А. К. Матвеева, в 2011 г. Это уже упомянутая книга о мансийской топонимии [Матвеев, 2011], монография Н. В. Кабининой по субстратной топонимии Архангельского Поморья [Кабинина, 2011], пятый том Словаря говоров Русского Севера [СГРС], топонимический словарь р. Чусовой [Иванова].

Результаты работы Уральской топонимической школы постоянно приумножаются. Изучение субстратной топонимии, оставаясь центральным, не заслоняло интереса к русской лексической архаике обеих изучаемых территорий [Матвеев, 1987a; и др.]. Да и вообще в рамках школы всегда были уважаемы личные пристрастия ученых, что имело следствием расширение проблематики. М. Э. Рут от изучения русской народной астронимии [Рут, 1975] пришла к широкой теме образной номинации в русском языке [Рут, 1992]; М. В. Голомидова занималась искусственной номинацией в топонимии, а затем в ономастике в целом [Голомидова, 1987; 1998]; Е. Л. Березович опре-

\footnotetext{
${ }^{6}$ См.: [Матвеев, 1996; 1997b; 1998; 2006].
} 
делила сферой своих интересов этнолингвистику [Березович, 1992; 1999; 2014], развивая со своими учениками соответствующее научное направление; А. А. Фомин, занимавшийся озерными гидронимами [Фомин, 1986], позднее сосредоточил свои разработки на проблемах литературной ономастики [Фомин, 2012]. В центральной - топонимической - зоне шло географическое расширение. Например, Т. Н. Дмитриева от лексических заимствований в русских говорах Нижнего Прииртышья [Дмитриева, 1981] вышла на исследование топонимии бассейна реки Казым и, применив энциклопедический подход к материалу, показала значимость данного класса имен для выводов о языке, истории и культуре населения Казыма - ханты, манси, ненцев, коми, русских [Дмитриева, 2005].

Представители Уральской научной школы следуют девизу A. К. Матвеева, он любил фразу Данте «Segui il tuo corso» [«Следуй своим путем», 2006]. Объединяют исследователей общие принципы работы и нацеленность на итоговое лексикографическое оформление ее результатов. Много лет шло создание многотомного Словаря русских говоров Среднего Урала [СРГСУ; СРГСУ (доп)], большинство его томов редактировал А. К. Матвеев, в настоящее время издается многотомный Словарь говоров Русского Севера [СГРС].

Видоизменяясь, школа А. К. Матвеева хранит верность заложенным им основам научного исследования слова как памятника русской духовной культуры.

\section{Граду и миру}

Социальный темперамент А. К. Матвеева не позволял ему замыкаться в сугубо научных рамках. Популяризация науки не является обязанностью ученого, для занятий ею нужно иметь личную предрасположенность, особую жилку. У профессора Матвеева такая жилка, безусловно, была. Его привлекала задача распространения научных знаний, он с интересом откликался на предложения о научно-популярных публикациях и настаивал на том, что они в полной мере остаются научными.

А. К. Матвееву принадлежит авторство нескольких топонимических словарей, адресованных широкому читателю [Матвеев, 1980; $1984 ; 1997 a ; 2000]$. Все они изданы на Урале и отражают уральские и сибирские географические названия. Манеру автора отличают научная емкость, четкость формулировок, продуманный аппарат изданий (обязательны списки использованных лингвистических терминов, литературы, сокращений), доступный массовому читателю характер изложения. А в словаре «Географические названия Тюменского Севера» даже предпринята такая акция: читателю предлагается самому участвовать в сборе географических названий и объясняется, как составлять словарь географических названий. Автор пишет: «Само по 
себе стремление раскрыть прошлое своей малой Родины, запечатленное в географических названиях, и увековечить его в словаре - естественное побуждение духовно богатой личности. А массовая гибель топонимов делает это благородное стремление общественно значимым» [Матвеев, $1997 a$, с. 182].

Замечательны также сборники научно-популярных статей и эссе о собственных именах [Матвеев, 1976; 1979; 1992], содержащих богатейшую фактографию как лингвистического, так и географического, исторического, этнографического плана. Для этих сочинений характерны занимательность (вот, например, названия некоторых очерков из книжки «Вверх по реке забвения»: В роли создателя; Семерка на карте; Ездил ли изарь по Царской дороге?; Федот, да не тот...; Дело о лжезырянах и т. п.), стилистика, предполагающая собеседование с читателем, чувство юмора, а также патриотизм, изредка - открытое наставление, напоминание о нравственности в обращении со словом. А. К. Матвеев как популяризатор науки не стеснялся пафоса, потому что выступал защитником русской культуры. Он планировал написать книгу для детей «Как говорили наши деды», сборники рассказов «Записки охотника за словами» и «Байки у костра», книжку «Рассказы о самых-самых» и др. Эти планы остались неосуществленными.

Многолетнее сотрудничество связывало А. К. Матвеева и журнал «Уральский следопыт». С сотрудниками этого журнала, уделяющего большое внимание краеведению и путешествиям, его сближали эти общие интересы, активность жизненной позиции, заинтересованность в читателе. Ю. А. Горбунов, зав. отделом истории и краеведения «Уральского следопыта», справедливо видит в этом содружестве продолжение «славной традиции просветителей XIX в., когда подлинным ученым считался тот, кто умел донести результаты своих исследований и открытий до широкой читательской аудитории» [Горбунов].

Еще одна линия обратной связи - этопереписка стопонимистами краеведами и туристами. Писали желающие заниматься топонимией, ревнители отечественной истории и словесности. Чувствуя недостаточность своей научной квалификации, они искали авторитетных специалистов, направляя первые письма по адресу издательств, вузов, редакций журналов. В личном архиве А. К. Матвеева сотни таких писем (часть их воспроизведена в книге «Не просто прожитая жизнь»). Профессор ценил интеллектуальные усилия людей разных профессий, почувствовавших вкус к словесным изысканиям, поддерживал их интерес, сохраняя при этом полную объективность взгляда. Разъяснял, предлагал, советовал, оценивал. Иногда такая переписка длилась годами. Но невежества и самонадеянности не терпел, в ответном письме называл вещи своими именами. Аргументируя, естественно, свое мнение.

Труды профессора Матвеева, адресованные широкой аудитории, востребованы среди краеведов, журналистов, туристов - всех интересующихся историей родного края. 
Итоговый сборник трудов А. К. Матвеева «Ономатология» открывается статьей «Апология имени». Но и вся его научная жизнь направлена на это. Апологет собственных имен - географических названий, поднявший их лингвистическую и историко-этническую ценность на огромную высоту. Блестящий этимолог и лингвоэтнолог, методолог-новатор, строгий и справедливый научный редактор. Талантливый организатор науки и неутомимый путешественник (77 личных экспедиционных выездов и бессчетное количество туристических походов). Охотник и благодарный созерцатель красоты родной русской природы. Меломан и музыкант-любитель, знаток и ценитель поэзии. Реалист и романтик. Человек, бесконечно преданный своему делу. И поэт.

Закончим эти заметки стихотворением А. К. Матвеева «Исповедь»:

\author{
Истекают минуты предательски, \\ Только год налетает на год... \\ Как давно я ушел в изыскательский \\ Очень дальний и трудный поход! \\ По следам неизвестного племени, \\ По словам, что оставила чудь, \\ Прохожу я в безмолвье и темени \\ Весь похищенный временем путь. \\ За горами да за долинами \\ Человеческих будничных дел \\ Я ищу те поля, где чудинами \\ Был засеян последний надел. \\ Под одними и теми же звездами \\ Вековые деревья шумят, \\ И звенят над чудскими погостами \\ Голоса деревенских девчат. \\ А в бездонном хранилище времени \\ По складам я читаю рассказ \\ О судьбе и о гибели племени, \\ Кровь которого может быть в нас.
}

\title{
Список литературы
}

Аникин А. E. От чуди до мери // Вопросы языкознания. 2001. № 6. С. 3-13.

Березович Е. Л. Русская лексика на общеславянском фоне: семантико-мотивационная реконструкция. М. : Русский фонд содействия образованию и науке, 2014. 487 с.

Березович Е. Л. Русская топонимия в этнолингвистическом аспекте : дис. ... д-ра филол. наук. Екатеринбург, 1999. 461 с.

Березович Е. Л. Семантические микросистемы в русской топонимии : дис. ... канд. филол. наук. Екатеринбург, 1992. 268 с.

Вброд через реку времени : 59 лет Топонимической экспедиции Уральского университета. Екатеринбург : Изд-во Уральского университета, 2011. 236 с. 
Востриков О. В. Духовный наставник // Не просто прожитая жизнь : Биография А. К. Матвеева в документах и воспоминаниях. Екатеринбург : Изд-во Уральского университета, 2015a. С. 172-175.

Востриков О. В. Мерянская линия А. К. Матвеева // Матвеев А. К. Субстратная топонимия Русского Севера. Ч. 4. Екатеринбург : Изд-во Уральского университета, 2015b. C. 19-22.

ВТ - Вопросы топономастики : Доклады кружка сравнительно-исторического языкознания / под ред. А. К. Матвеева. Свердловск : Типолаборатория УрГУ, 1962. 49 с.

Глинских $Г$. В. Русская топонимия мансийского происхождения в бассейне реки Тавды : дис. ... канд. филол. наук. Свердловск, 1972.

Голомидова М. В. Искусственная номинация в русской ономастике : дис. ... д-ра филол. наук. Екатеринбург, 1998. 375 с.

Голомидова М. В. Искусственная номинация в топонимии : дис. ... канд. филол. наук. Свердловск, 1987. 216 с.

Горбунов Ю. А. Свой человек в «Следопыте» // Не просто прожитая жизнь : Биография А. К. Матвеева в документах и воспоминаниях. Екатеринбург : Изд-во Уральского университета, 2015. С. 140.

Дмитриева Т. Н. Лексические заимствования в русских говорах Нижнего Прииртышья : дис. ... канд. филол. наук. Свердловск, 1981. 262 с.

Дмитриева Т. Н. Топонимия бассейна реки Казым. Екатеринбург : Изд-во Уральского университета, 2005. $580 \mathrm{c}$.

Иванова Е. Э. По Чусовой : Топонимический словарь. Екатеринбург : Изд-во Уральского университета, 2014. 160 с., схемы, ил. (Труды Топонимической экспедиции).

Лёвшина К. М. Мемуары // Урал. 2001. № 11. С. 104-163; № 12. С. 142-194.

Кабинина Н. В. «Но даже плохо когда, то все равно хорошо...» // Не просто прожитая жизнь : Биография А. К. Матвеева в документах и воспоминаниях. Екатеринбург : Изд-во Уральского университета, 2015. С. 190-192.

Кабинина H. В. Субстратная топонимия Архангельского Поморья. Екатеринбург : Изд-во Уральского университета, 2011. 316 с. (Труды Топонимической экспедиции).

Макарова А. А. К лексикографическому описанию озерной гидронимии Белозерья: словарь и электронная база данных // Этнолингвистика. Ономастика. Этимология : Материалы междунар. науч. конф. Екатеринбург, 8-12 сентября 2009 г. Екатеринбург, 2009. С. 166-168.

Матвеев A. K. Архаическая русская топонимия на северо-востоке Европейской части России // Вопросы языкознания. 1987a. № 21. С. 66-76.

Матвеев A. K. Вверх по реке забвения : Рассказы о географических названиях. Свердловск : Средне-Уральское книжное изд-во, 1992. 176 с.

Матвеев $A$. K. Географические названия Свердловской области : Топонимический словарь. Екатеринбург : Уральское литературное агентство, 2000. 359 с.

Матвеев A. K. Географические названия Тюменского Севера. Екатеринбург : Издво Уральского университета, 1997a. $191 \mathrm{c.}$

Матвеев А. К. Географические названия Урала. Свердловск : Средне-Уральское книжное изд-во, 1980. $318 \mathrm{c.}$

Матвеев А. К. К проблеме расселения летописной мери // Известия Уральского государственного университета. Гуманитарные науки. Вып. 1. № 7. Екатеринбург, 1997b. C. $5-17$.

Матвеев $A$. K. Материалы по мансийской топонимии горной части Северного Урала. Екатеринбург : Изд-во Уральского университета, 2011. 255 с.

Матвеев A. K. Мерянская топонимия на Русском Севере - фантом или феномен? // Вопросы языкознания. 1998. № 5. С. 90-105.

Матвеев А. К. Методы топонимических исследований : учебное пособие. Свердловск : Типолаборатория УрГУ, 1986. $101 \mathrm{c}$.

Матвеев A. K. Нёройки караулят Урал : Путешествие в топонимию. Свердловск : Средне-Уральское книжное изд-во, 1976. 215 с. 
Матвеев А. K. О древнем субстрате в топонимии Уральского Севера // Формирование и развитие топонимии : Сб. науч. тр. Свердловск : Изд-во Уральского университета, 1987b. С. 22-28.

Матвеев А. К. Ономатология. М. : Наука, 2006. 291 с.

Матвеев $A$. K. От Пай-Хоя до Мугоджар: Названия уральских хребтов и гор. Свердловск : Средне-Уральское книжное изд-во, 1984. 272 с. 157.

Матвеев А. К. Последняя из калмажей // Уральский следопыт. 1964. № 1. С. 154

Матвеев $A$. K. Русская топонимика финно-угорского происхождений на территории севера Европейской части СССР : дис. ... д-ра филол. наук / АН СССР ; Ин-т русского языка АН СССР, 1970. Т. 1. С. 1-241; Т. 2. С. 242-581; Приложения 101 с.: Карты, 86 с. [Машинопись].

Матвеев А. К. Семь названий на карте Урала. Свердловск, 1979. 127 с.

Матвеев А. К. Субстратная топонимия Русского Севера. Ч. 1. Екатеринбург : Издво Уральского университета, 2001. 346 с., 7 карт.

Матвеев А. К. Субстратная топонимия Русского Севера. Ч. 2. Екатеринбург : Издво Уральского университета, 2004. 369 с., 32 карты.

Матвеев А. К. Субстратная топонимия Русского Севера. Ч. 3. Екатеринбург : Издво Уральского университета, 2007. 297 с., 8 карт.

Матвеев А. К. Субстратная топонимия Русского Севера. Ч. 4. Топонимия мерянского типа. Екатеринбург : Изд-во Уральского университета, 2015. 313 с., 21 карта.

Матвеев А. К. Субстратная топонимия Русского Севера и мерянская проблема // Вопросы языкознания. 1996. №1. С. 3-23.

Матвеев А. К. Финно-угорские заимствования в русских говорах Северного Урала // Ученые записки Уральского государственного университета : Языкознание. Вып. 32. Свердловск, 1959. С. 3-123.

Матвеев Александр Константинович : Библиографический указатель. Екатеринбург, 1996. $60 \mathrm{c.}$

Мищенко О. В. Электронная база данных «Топонимия Костромской области»: обработка и систематизация полевого материала // Вопросы ономастики. 2011. № 2 (11). C. $89-104$.

Не просто прожитая жизнь : Биография А. К. Матвеева в документах и воспоминаниях / сост. Т. В. Матвеева. Екатеринбург : Изд-во Уральского университета, 2015. 640 с.; ил.

Николаева E. С. Электронная картотека топонимии Русского Севера: проблемы и перспективы // Финно-угорское наследие в русском языке. Вып. 1. Екатеринбург, 2000. C. $143-154$.

Рут М. Э. Образная номинация в русском языке. Екатеринбург : Изд-во Уральского университета, 1992. $147 \mathrm{c.}$

Рут M. Э. Русская народная астронимия и ее связи с астронимией других народов СССР : дис. ... канд. филол. наук. Свердловск. 1975. 168 с.

Pуm M. Э., Березович Е. Л. Во главе научной школы // Не просто прожитая жизнь : Биография А. К. Матвеева в документах и воспоминаниях. Екатеринбург : Изд-во Уральского университета, 2015. С. 71-78.

«Следуй своим путем... : : Интервью к 80-летию профессора А. К. Матвеева // Известия Уральского университета. 2006. № 41. Сер. «Гуманитарные науки». Вып. 11. C. $320-321$.

Слинкина Т. Д. Мансийские оронимы Урала. Ханты-Мансийск : Новости Югры, 2011. 480 с., ил.

Смирнов О. В. От составителя // Матвеев А. К. Субстратная топонимия Русского Севера. Ч. 4. Екатеринбург : Изд-во Уральского университета, 2015. С. 6-18.

Смирнов О. В. Русская топонимия северной части Горнозаводского Урала : дис. ... канд. филол. наук. Свердловск, 1997.

СРГСУ - Словарь русских говоров Среднего Урала. Т. 1-7. Свердловск ; Екатеринбург : Изд-во Уральского университета, 1964-1988. 
СРГСУ(доп) - Словарь русских говоров Среднего Урала. Дополнения. Екатеринбург : Изд-во Уральского университета, 1996. 580 с.

СГРС - Словарь говоров Русского Севера. Т. 1-5. Екатеринбург : Изд-во Уральского университета, 2001-2011.

Фомин А. А. Квадратура круга семьи Карениных: об ассоциативном потенциале двух фамилий героини романа Л. Н. Толстого // Вопросы ономастики. 2012. № 2 (13). C. $63-82$.

Фомин А. А. Семантическая типология озерных гидронимов Зауралья : дис. ... канд. филол. наук. Свердловск, 1986. 208 с.

Язык и прошлое народа : Сб. науч. ст. памяти проф. А. К. Матвеева / отв. ред. М. Э. Рут. Екатеринбург, 2012. 513 с.

\section{References}

Anikin, A. E. (2001). Ot chudi do meri [From Chud' to Merya]. In Voprosy' yazy'koznaniya, 6, pp. 3-13.

Berezovich, E. L. (2014). Russkaya leksika na obshheslavyanskom fone: semantiko-motivacionnaya rekonstrukciya [Russian Lexis against the General Slavic Background: A Semantic-Motivational Reconstruction]. 487 p. Moscow, Russkij fond sodejstviya obrazovaniyu i nauke.

Berezovich, E. L. (1999). Russkaya toponimiya v e'tnolingvisticheskom aspekte [Russian Toponymy in the Ethnolinguistic Aspect]. (A Doctoral Thesis in Philology). 461 p. Yekaterinburg.

Berezovich, E. L. (1992). Semanticheskie mikrosistemy'v russkoj toponimii [Semantic Microsystems in Russian Toponymy]. (A PhD Thesis in Philology). 268 p. Yekaterinburg.

Dmitrieva, T. N. (1981). Leksicheskie zaimstvovaniya v russkih govorah Nizhnego Priirty'sh'ya [Lexical Loans in the Russian Subdialects of the Low Irtysh Basin]. (A PhD Thesis in Philology). 262 p. Sverdlovsk.

Dmitrieva, T. N. (2005). Toponimiya bassejna reki Kazy'm [The Toponymy of the Kazym River Basin]. 580 p. Yekaterinburg, Izdatel'stvo Ural'skogo universiteta.

Fomin, A. A. (2012). Kvadratura kruga sem'i Kareniny'h: ob associativnom potenciale dvuh familij geroini romana L. N. Tolstogo [Squaring the Circle of the Karenin Family: On the Associative Potential of the Two Surnames of the Heroine of the Novel]. In Voprosy' onomastiki, 2 (13), pp. 63-82.

Fomin, A. A. (1986). Semanticheskaya tipologiya ozerny'h gidronimov Zaural'ya [Semantic Typology of the Lake Hydronyms of the Trans-Urals]. (A PhD Thesis in Philology). 208 p. Sverdlovsk.

Glinskih, G. V. (1972). Russkaya toponimiya mansijskogo proishozhdeniya v bassejne reki Tavdy' [Russian Toponymy of Mansi Origin in the Tavda River Basin]. (A PhD Thesis in Philology). Sverdlovsk.

Golomidova, M. V. (1998). Iskusstvennaya nominaciya v russkoj onomastike [Artificial Nomination in Russian Onomastics]. (A Doctoral Thesis in Philology). 375 p. Yekaterinburg.

Golomidova, M. V. (1987). Iskusstvennaya nominaciya v toponimii [Artificial Nomination in Toponymy]. (A PhD Thesis in Philology). 216 p. Sverdlovsk.

Gorbunov, Yu. A. (2015). Svoj chelovek v «Sledopy'te» [A Cater Cousin in Sledopyt]. In Ne prosto prozhitaya zhizn': Biografiya A. K. Matveeva v dokumentah i vospominaniyah (p. 140). Yekaterinburg, Izdatel'stvo Ural'skogo universiteta.

Ivanova, E. E'. (2014). Po Chusovoj: Toponimicheskij slovar' [Down the Chusovaya River: A Dictionary of Toponymy]. (Trudy' Toponimicheskoj e'kspedicii). 160 p. Yekaterinburg, Izdatel'stvo Ural'skogo universiteta.

Levshina, K. M. (2001). Memuary' [Memoirs]. In Ural, 11, pp. 104-163; 12, pp. 142194. 
Kabinina, N. V. (2015). «No dazhe ploho kogda, to vse ravno horosho...» ["But even if one feels down, it's still good"...]. In Ne prosto prozhitaya zhizn': Biografiya A. K. Matveeva v dokumentah $i$ vospominaniyah (pp. 190-192). Yekaterinburg, Izdatel'stvo Ural'skogo universiteta.

Kabinina, N. V. (2011). Substratnaya toponimiya Arhangel'skogo Pomor'ya [Substrate Toponymy of Archangelsk Pomorye]. (Trudy'Toponimicheskoj e'kspedicii). 316 p. Yekaterinburg, Izdatel'stvo Ural'skogo universiteta.

Makarova, A. A. (2009). K leksikograficheskomu opisaniyu ozernoj gidronimii Belozer'ya: slovar' i e'lektronnaya baza danny'h [On the Lexicographic Description of Lake Hydronymy of Belozerye: A Dictionary and a Digital Database]. In E'tnolingvistika. Onomastika. E'timologiya: Materialy' mezhdunarodnoj nauchnoj konferencii. Ekaterinburg, 8-12 sentyabrya 2009 g. (pp. 166-168). Yekaterinburg.

Matveev, A. K. (1987). Arhaicheskaya russkaya toponimiya na severo-vostoke Evropejskoj chasti Rossii [Archaic Russian Toponymy in the Northeast of European Russia]. In Voprosy' yazy'koznaniya, 21, pp. 66-76.

Matveev, A. K. (1959). Finno-ugorskie zaimstvovaniya v russkih govorah Severnogo Urala [Finno-Ugric Loan Words in the Russian Subdialects of the Northern Urals]. In Ucheny'e zapiski Ural'skogo gosudarstvennogo universiteta: Yazy'koznanie (Iss. 32, pp. 3-123). Sverdlovsk.

Matveev, A. K. (2000). Geograficheskie nazvaniya Sverdlovskoj oblasti: Toponimicheskij slovar' [Place Names of Sverdlovsk Region: A Dictionary of Toponyms]. 359 p. Yekaterinburg, Ural'skoe literaturnoe agentstvo.

Matveev, A. K. (1997). Geograficheskie nazvaniya Tyumenskogo Severa [Place Names of the Tyumen' North]. 191 p. Yekaterinburg, Izdatel'stvo Ural'skogo universiteta.

Matveev, A. K. (1980). Geograficheskie nazvaniya Urala [Place Names of the Urals]. 318 p. Sverdlovsk, Sredne-Ural'skoe knizhnoe izd-vo.

Matveev, A. K. (1997). K probleme rasseleniya letopisnoj meri [On the Issue of Chronicle Merya Settlement]. In Izvestiya Ural'skogo gosudarstvennogo universiteta. Gumanitarny'e nauki (Iss. 1/7, pp. 5-17). Yekaterinburg.

Matveev, A. K. (2011). Materialy' po mansijskoj toponimii gornoj chasti Severnogo Urala [Materials on the Mansi Toponymy of the Mountainous Part of the Northern Urals]. Yekaterinburg, Izdatel'stvo Ural'skogo universiteta.

Matveev, A. K. (1998). Meryanskaya toponimiya na Russkom Severe - fantom ili fenomen? [Merya Toponymy in the Russian North - A Phantom or a Phenomenon?]. In Voprosy' yazy'koznaniya, 5, pp. 90-105.

Matveev, A. K. (1986). Metody' toponimicheskih issledovanij: uchebnoe posobie [Methods of Toponymic Research: A Manual]. 101 p. Sverdlovsk, Tipolaboratoriya UrGU.

Matveev, A. K. (1976). Nyorojki karaulyat Ural: Puteshestvie v toponimiyu [Nyoroikas Watch the Urals: A Travel into Toponymy]. 215 p. Sverdlovsk, Sredne-Ural'skoe knizhnoe izdatel'stvo.

Matveev, A. K. (1987). O drevnem substrate v toponimii Ural'skogo Severa [On the Old Substrate in the Toponymy of the Ural North]. In Formirovanie $i$ razvitie toponimii: Sbornik nauchny'h trudov (pp. 22-28). Sverdlovsk \& Yekaterinburg, Izdatel'stvo Ural'skogo universiteta.

Matveev, A. K. (2006). Onomatologiya [Onomatology]. 291 p. Moscow, Nauka.

Matveev, A. K. (1984). Ot Paj-Hoya do Mugodzhar: Nazvaniya ural'skih hrebtov i gor [From the Pay-Khoy Ridge to Mugodzhar Hills: Ural Mountain Chains Names]. 272 p. Sverdlovsk, Sredne-Ural'skoe knizhnoe izdatel'stvo.

Matveev, A. K. (1964). Poslednyaya iz kalmazhej [The Last of the Kamasins]. In Ural'skij sledopy't, 1, pp. 154-157.

Matveev, A. K. (1970). Russkaya toponimika finno-ugorskogo proishozhdenij na territorii severa Evropejskoj chasti SSSR [Russian Toponymy of Finno-Ugric Origin on the Territory of the European Part of the USSR]. (A Doctoral Thesis in Philology). Vol. 1, pp. 1-241; Vol. 2, pp. 242-581. AN SSSR, Institut russkogo yazy'ka AN SSSR. 
Matveev, A. K. (1979). Sem' nazvanij na karte Urala [Seven Names on the Map of the Urals].127 p. Sverdlovsk.

Matveev, A. K. (2001). Substratnaya toponimiya Russkogo Severa [Substrate Toponymy of the Russian North]. Part 1. 346 p. Yekaterinburg, Izdatel'stvo Ural'skogo universiteta.

Matveev, A. K. (2004). Substratnaya toponimiya Russkogo Severa [Substrate Toponymy of the Russian North]. Part 2. 369 p. Yekaterinburg, Izdatel'stvo Ural'skogo universiteta.

Matveev, A. K. (2007). Substratnaya toponimiya Russkogo Severa [Substrate Toponymy of the Russian North]. Part 3. 297 p. Yekaterinburg, Izdatel'stvo Ural'skogo universiteta.

Matveev, A. K. (2015). Substratnaya toponimiya Russkogo Severa [Substrate Toponymy of the Russian North]. Part 4. 313 p. Toponimiya meryanskogo tipa. Yekaterinburg, Izdatel'stvo Ural'skogo universiteta.

Matveev, A. K. (1996). Substratnaya toponimiya Russkogo Severa i meryanskaya problema [Substrate Toponymy of the Russian North and the Merya Issue]. In Voprosy' yazy'koznaniya, 1, pp. 3-23.

Matveev, A. K. (1992). Vverh po reke zabveniya: Rasskazy' o geograficheskih nazvaniyah [Up the River of Oblivion: Stories of Place Names]. Sverdlovsk, SredneUral'skoe knizhnoe izdatel'stvo.

Matveev, A. K. (Ed.). (1962). Voprosy' toponomastiki: Doklady' kruzhka sravnitel'noistoricheskogo yazy'koznaniya [Problems of Toponomastics: Reports of the Circle of Comparative Linguistics]. 49 p. Sverdlovsk, Tipolaboratoriya UrGU.

Matveev Aleksandr Konstantinovich: Bibliograficheskij ukazatel' [Matveev Aleksandr Konstantinovich: A Bibliographic Index]. (1996). 60 p. Yekaterinburg.

Mishhenko, O. V. (2011). E'lektronnaya baza danny'h «Toponimiya Kostromskoj oblasti»: obrabotka i sistematizaciya polevogo materiala [Electronic Database "Toponymy of Kostroma Region": Material Processing and Systematization]. In Voprosy' onomastiki, 2 (11), pp. 89-104.

Matveeva, T. V. (Comp.) (2015). Ne prosto prozhitaya zhizn': Biografiya A. K. Matveeva v dokumentah i vospominaniyah [ALife That Was not Easy: A. K. Matveev's Biography in Documents]. 640 p. Yekaterinburg, Izdatel'stvo Ural'skogo universiteta.

Nikolaeva, E. S. (2000). E'lektronnaya kartoteka toponimii Russkogo Severa: problemy' i perspektivy' [An Electronic File Index of the Toponymy of the Russian North: Issues and Prospects]. In Finno-ugorskoe nasledie v russkom yazy'ke (Iss. 1, pp. 143-154). Yekaterinburg.

Rut, M. E'. (1992). Obraznaya nominaciya v russkom yazy'ke [Image Nomination in the Russian Language]. 147 p. Yekaterinburg, Izdatel'stvo Ural'skogo universiteta.

Rut, M. E'. (1975). Russkaya narodnaya astronimiya i ee svyazi s astronimiej drugih narodov SSSR [Russian Folk Astronymy and Its Connections with the Astronymy of Other USSR Peoples]. (A PhD Thesis in Philology). 168 p. Sverdlovsk.

Rut, M. E'. (Ed.). (2012). Yazy'k i proshloe naroda: Sbornik nauchny'h statej pamyati prof. A. K. Matveeva [Language and the Nation's Past: A Collection of Scholarly Articles in Memoriam of A. K. Matveev]. 513 p. Yekaterinburg.

Rut, M. E'. \& Berezovich, E. L. (2015). Vo glave nauchnoj shkoly' [At the Head of a School of Thought]. In Ne prosto prozhitaya zhizn': Biografiya A. K. Matveeva v dokumentah $i$ vospominaniyah (pp. 71-78). Yekaterinburg, Izdatel'stvo Ural'skogo universiteta.

«Sleduj svoim putem...»: Interv'yu k 80-letiyu professora A. K. Matveeva [Go Your Own Way: An Interview for Professor A. K. Matveev's 80 ${ }^{\text {th }}$ Birthday]. (2006). In Izvestiya Ural'skogo universiteta, 41. Ser. "Gumanitarny'e nauki» (Iss. 11, pp. 320-321).

Slinkina, T. D. (2011). Mansijskie oronimy' Urala [Mansi Oronyms of the Urals]. 480 p. Khanty-Mansiysk, Novosti Yugry'.

Smirnov, O. V. (2015). Ot sostavitelya [From the Compiler]. In Matveev, A. K. Substratnaya toponimiya Russkogo Severa (Part 4, pp. 6-18). Yekaterinburg, Izdatel'stvo Ural'skogo universiteta. 
Smirnov, O. V. (1997). Russkaya toponimiya severnoj chasti Gornozavodskogo Urala [Russian Toponymy of the Northern Part of the Mining Urals]. (A PhD Thesis in Philology). Sverdlovsk.

Slovar' govorov Russkogo Severa [A Dictionary of the Subdialects of the Russian North]. (2001-2011). Vols. 1-5. Yekaterinburg, Izdatel'stvo Ural'skogo universiteta.

Slovar' russkih govorov Srednego Urala [A Dictionary of the Russian Subdialects of the Middle Urals]. (1964-1988). Vols. 1-7. Sverdlovsk, Yekaterinburg, Izdatel'stvo Uralskogo universiteta.

Slovar' russkih govorov Srednego Urala. Dopolneniya [A Dictionary of the Russian Subdialects of the Middle Urals. Supplement]. (1996). 580 p. Yekaterinburg, Izdatel'stvo Ural'skogo universiteta.

Vbrod cherez reku vremeni: 59 let Toponimicheskoj e'kspedicii Ural'skogo universiteta [Wading across the River of Time: 59 Years of the Toponymic Expedition of Ural University]. (2011). 236 p. Yekaterinburg, Izdatel'stvo Ural'skogo universiteta.

Vostrikov, O. V. (2015). Duhovny'j nastavnik [A Spiritual Advisor]. In Ne prosto prozhitaya zhizn': Biografiya A. K. Matveeva v dokumentah i vospominaniyah (pp. 172175). Yekaterinburg, Izdatel'stvo Ural'skogo universiteta.

Vostrikov, O. V. (2015). Meryanskaya liniya A. K. Matveeva [The Merya Line of A. K. Matveev]. In Matveev, A. K. Substratnaya toponimiya Russkogo Severa (Part 4, pp. 19-22). Yekaterinburg, Izdatel'stvo Ural'skogo universiteta.

The article was submitted on 15.06.2015

Тамара Вячеславовна Матвеева, профессор,

Уральский федеральный

университет,

Екатеринбург, Россия

tomat-44@mail.ru

\author{
Валентин Петрович Лукьянин, \\ кандидат философских наук, \\ член Союза российских писателей, \\ Екатеринбург, Россия \\ lukianin@convex.ru
}

Tamara Matveeva, Professor, Ural Federal University, Yekaterinburg, Russia tomat-44@mail.ru 